\title{
A SIMPLE CRYOPRESERVATION METHOD OF HUMAN BLOOD FOR CHROMOSOME STUDY ${ }^{1}$
}

\author{
Koji Kondo and Motomichi SASAKI \\ Chromosome Research Unit, Faculty of Science, Hokkaido University, \\ Sapporo 060, Japan
}

\begin{abstract}
Summary A method is described of cryopreservation of human lymphocytes for cytogenetic studies. An aliquot of whole blood is pre-incubated in a PHA-added medium for at least one hour at $37^{\circ} \mathrm{C}$, and then stored frozen at $-140^{\circ} \mathrm{C}$ in Eagle's MEM containing $10 \%$ fetal bovine serum and $10 \%$ DMSO for various periods up to one year. Thawing is made quickly in a water-bath at $37^{\circ} \mathrm{C}$. After thorough washing with $\mathrm{MEM}$, the routine PHA-added blood culture method is applied, and airdried chromosome preparations are made. The results are highly reproducible with a good number of mitotic cells sufficient for karyotyping.
\end{abstract}

\section{INTRODUCTION}

Lymphocyte culture methods have been widely used for routine chromosome examinations, because of the easiness for obtaining specimens, simplicity of the procedures and a high reproducibility. However, blood samples stored for a long period at room temperature or in an ordinary refrigerator $\left(0-4^{\circ} \mathrm{C}\right)$, degenerate and fail to grow in culture. A need is growing for long-term preservation of blood samples in such cases as (1) repeated samplings from the same individuals are difficult or impossible, (2) a large number of samples collected can not be processed at one time, (3) transportation is required, and (4) reexamination is expected by newer techniques, e.g., the high resolution banding (Yunis, 1976).

We attempted to develop a simple and reliable method of cryopreservation of human blood lymphocytes for cytogenetic analyses in order to meet the requirements mentioned above.

\section{MATERIALS AND METHODS}

One $\mathrm{ml}$ of heparinized whole blood or 1-2 $\times 10^{6}$ lymphocytes separated by either Lymphoprep (Nyegaard \& Co. As. Oslo) or Phytohemagglutinin (PHA-P, Diffco Lab., Detroit) were suspended in $1 \mathrm{ml}$ of Eagle's minimum essential medium (MEM) containing $10 \%$ fetal bovine serum and a preservative, $10 \%$ dimethyl sul-

Received April 6, 1981

${ }^{1}$ This work was supported by a grant from the Ministry of Health and Welfare, Japan. 
foxide (DMSO, spectro grade, Tokyo Kasei Kogyo Co., Ltd.) or 10\% glycerol. The cell suspension was sealed in a $2 \mathrm{ml}$ screw-capped glass vial (Wheaton Scientific, Millville), kept at $4^{\circ} \mathrm{C}$ for $1 \mathrm{hr}$, and then stored in the vapor phase $\left(-140^{\circ} \mathrm{C}\right)$ of a liquid nitrogen container (Dalic-350B, Osaka Sanso Kogyo Co., Ltd., Osaka) for various periods up to 1 year. Thawing was rapidly done in a water-bath at $37^{\circ} \mathrm{C}$. After thorough washing with MEM, the cells were routinely cultured for $72 \mathrm{hr}$ with PHA-P (final concentration, $0.001 \%$ ). The cultured celis were exposed to Colcemid $\left(0.05 \mu \mathrm{g} / \mathrm{ml}\right.$, for $1.5 \mathrm{hr}$ at $\left.37^{\circ} \mathrm{C}\right)$, followed by hypotonic treatment $(0.075 \mathrm{M} \mathrm{KCl}$, for $15 \mathrm{~min}$ at $\left.37^{\circ} \mathrm{C}\right)$ and fixation in methanol-acetic acid $(3: 1)$, and then air-dried on clean slides. For each sample, mitotic index was scored on the basis of 2,000 cells. Freezing experiments were also made with cultured blood cells, for $1 \mathrm{hr}, 1$ day, 2 days or 3 days at $37^{\circ} \mathrm{C}$ in the presence of PHA. They were stored frozen and thawed as in the same manner described above, and recultured for 3 days to 1 day. As control a PHA-stimulated whole blood culture was prepared in each experiment, before freezing.

\section{RESULTS}

A total of 35 blood samples taken from 30 healthy donors with a normal karyotype and from 5 Down's syndrome patients were used for the present experiments. Preliminary experiments indicated that cultures made from whole blood generally yielded a higher mitotic index than those from isolated lymphocytes, and that DMSO was better than glycerol as a protective agent (data not shown). Henceforth only results obtained in experiments from whole blood and DMSO will be described. As shown in Table 1, cultures stimulated with PHA for only $1 \mathrm{hr}$, before freezing, showed consistently a higher mitotic rate as compared to those prepared from directly frozen blood without PHA. Similarly good results were obtained for cells cultured with PHA for 1 to 3 days before freezing. There was no appreciable difference in the mitotic index among the cells stored for a few days to 1 year.

The results obtained from 5 Down's syndrome children were essentially the same as above (Table 2).

Generally, mitotic indices of non-frozen control cultures appeared to be higher than those of experimental cultures, but the reverse was true for some cases, especially in one case of Down's syndrome (Table 2). Also shown was that directly frozen lymphocytes immediately after separation by PHA yielded better results, though only occasionally, than those separated by Lymphoprep.

\section{DISCUSSION}

The above results clearly show that cryopreserved human whole blood after short-term stimulation or culture with PHA provides a favorable means for cytogenetic studies. Similar techniques have already been developed by using directly 
Table 1. Mitotic indices $(\%)$ in cultures recovered from frozen whole blood of karyotypically normal subjects.

\begin{tabular}{|c|c|c|c|c|c|c|c|}
\hline \multirow{2}{*}{ No. } & \multirow{2}{*}{$\begin{array}{c}\text { Duration } \\
\text { of } \\
\text { freezing }\end{array}$} & \multirow{2}{*}{ Control a } & \multicolumn{5}{|c|}{ Duration of stimulation with PHA before freezing b } \\
\hline & & & 0 & $1 \mathrm{hr}$ & 1 day & 2 days & 3 days \\
\hline 1 & 6 days & 4.3 & 1.1 & 3.7 & & & \\
\hline 2 & 6 days & 7.8 & 3.4 & 4.5 & 4.6 & & \\
\hline 3 & 6 days & 10.6 & 2.3 & 3.8 & 4.6 & & \\
\hline 4 & 15 days & 4.3 & 1.0 & & 4.3 & & \\
\hline 5 & 19 days & 4.9 & 0.8 & & 4.4 & & \\
\hline 6 & 3 mo. & 6.8 & 2.3 & 3.8 & 5.6 & & \\
\hline 7 & $3 \mathrm{mo}$. & 6.9 & 4.7 & 6.3 & 3.3 & & \\
\hline 8 & $12 \mathrm{mo}$. & 4.7 & & & 2.8 & & \\
\hline 9 & $12 \mathrm{mo}$. & 6.1 & & & 4.2 & & \\
\hline 10 & $12 \mathrm{mo}$. & 2.3 & & & & 3.7 & \\
\hline 11 & $12 \mathrm{mo}$. & 7.0 & & & & 1.5 & \\
\hline 12 & $12 \mathrm{mo}$. & 3.7 & & & & & 3.6 \\
\hline \multirow[t]{3}{*}{13} & $12 \mathrm{mo}$. & 5.9 & & & & & 2.7 \\
\hline & Mean & 5.8 & 2.2 & 4.4 & 4.2 & 2.6 & 3.2 \\
\hline & S.E. & 0.59 & 0.54 & 0.49 & 0.30 & 1. 10 & 0.45 \\
\hline
\end{tabular}

a Control, routine 3-day-cultures without freezing. b 0 : Direct freezing without PHA. $0,1 \mathrm{hr}$ : Cultures are continued for 3 days after thawing. 1 day: Cultures are continued for 2 days after thawing. 2, 3 days: Cultures are continued for 1 day after thawing.

Table 2. Mitotic indices $(\%)$ in cultures recovered from frozen whole blood of Down's syndrome patients.

\begin{tabular}{cccccccc}
\hline \multirow{2}{*}{ No. } & $\begin{array}{c}\text { Duration } \\
\text { of } \\
\text { freezing }\end{array}$ & Control a & \multicolumn{6}{c}{ Duration of stimulation with PHA before freezing b } \\
\cline { 4 - 8 } & & 0 & 1 hr & 1 day & 2 days & 3 days \\
\hline 1 & 6 days & 7.5 & 2.2 & 2.2 & 4.5 & & \\
2 & 13 days & 3.9 & 8.6 & & & & \\
3 & 5 mo. & & 1.3 & 2.0 & 3.1 & & \\
4 & 12 mo. & 2.1 & & & & 8.7 & 3.3 \\
5 & 13 mo. & 2.5 & & & & & 3.3 \\
\hline & Mean & 4.0 & 4.0 & 2.1 & 3.8 & 8.7 & 3.3 \\
& S.E. & 1.23 & 2.30 & 0.1 & 0.7 & & \\
\hline
\end{tabular}

a, b : See the footnote in Table 1. 
frozen lymphocytes (Pegg, 1965) or whole blood (Weed et al., 1972). DMSO has been superior to glycerol as a preservative against freezing injury for human and bovine red blood cells (Lovelock and Bishop, 1959), bone marrow cells and lymphocytes of the mouse (Ashwood-Smith, 1961, 1964), cultured chick embryo cells (Dougherty, 1962), as well as human lymphocytes (Berman et al., 1968).

Our results further revealed that blood cells frozen after stimulation with PHA retained higher mitotic potential than those frozen directly. Although the reason for this is not fully elucidated at present, the observed fact may bear both practical and theoretical importance. It may be worth-mentioning in this context that cultured Chinese hamster cells frozen in $\mathrm{M}$ and late $\mathrm{S}$ phases showed a higher survival rate than those frozen in $G_{2}$ phase (Koch et al., 1970), and that the survival of cells against freezing was largely dependent on the permeability of the cell membrane which affected the growth of intracellular ice crystals (Mazur, 1970). It has been known that non-stimulated lymphocytes are in resting or $G_{0}$ stage, which enter into the cyclic phase by adding PHA. Also known is that the PHA stimulation induces certain changes in the cell membrane of lymphocytes as triggered by increased turnover and interconversion of phospholipids within $1 \mathrm{hr}$, and that phosphorylation of nuclear protein and increase of RNA synthesis occur within $30 \mathrm{~min}$, and DNA synthesis begins by $24 \mathrm{hr}$ (Douglas, 1971; Hirschhorn and Hirschhorn, 1974).

In conclusion, cryopreservation, in the $10 \%$ DMSO medium, of whole blood after $1 \mathrm{hr}$ PHA-stimulation is thought to provide a workable protocol for cytogenetic analyses, of both karyotypically normal and abnormal subjects. The procedure is simple and the results are highly reproducible for at least one year of storage.

\section{REFERENCES}

Ashwood-Smith, M.J. 1961. Preservation of mouse bone marrow at $-79^{\circ} \mathrm{C}$ with dimethyl sulphoxide. Nature 190: 1204-1205.

Ashwood-Smith, M.J. 1964. Low temperature preservation of mouse lymphocytes with dimethyl sulphoxide. Blood 23: 494-501.

Berman, L., Goeman, C., and Peterson, W.D. 1968. Viability of frozen lymphocytes. Lancet i: 89.

Dougherty, R.M. 1962. Use of dimethyl sulphoxide for preservation of tissue culture cells by freezing. Nature 193: 550-552.

Douglas, S.D. 1971. Human lymphocyte growth in vitro: morphologic, biochemical, and immunologic significance. Int. Rev. Exp. Path. 10: 41-114.

Hirschhorn, K., and Hirschhorn, R. 1974. Mechanisms of lymphocyte activation. In: Mechanisms of Celi-Mediated Immunity. R.T. McCluskey and S. Cohen, eds., John Wiley and Sons, Inc., NY. pp. 115-134.

Koch, G.J., Kruuv, J., and Bruckschwaiger, C.W. 1970. Survival of synchronized Chinese hamster cells following freezing in liquid nitrogen. Exp. Cell Res. 63: 476-477.

Lovelock, J.E., and Bishop, M.W.H. 1959. Prevention of freezing damage to living cells by dimethyl sulphoxide. Nature 183: 1394-1395.

Mazur, P. 1970. Cryobiology: The freezing of biological systems. Science 168: 939-949.

Jpn. J. Human Genet. 
Pegg, P.J. 1965. The preservation of leucocytes for cytogenetic and cytochemical studies. Brit. J. Haemat. 11: 586-591.

Weed, R.G., Curcuru, F.M., and Jenkins, E.C. 1972. The cryogenic preservation of human whole blood inoculum for short-term leucocyte chromosome microculture. Cryobiology 9: 273-276.

Yunis, J.J. 1976. High resolution of human chromosomes. Science 191: 1268-1270. 